\title{
THE INVESTMENT BANKERS' CASE: A SURREJOINDER
}

\author{
WH. DWIGHT WHITHEY广
}

Professor Steffen's "Observations in Rejoinder" contain substantially no answers on the merits of the case, with which my article was primarily concerned. He refers to my identification of a second revolution in investment banking-“after 1937"-merely as an "intriguing thought."' $\mathrm{He}$ omits any comment on my demarcation of an earlier revolution dating from 1933. - Indeed, the key to the differences between us lies perhaps in this disregard on Professor Steffen's part for the merits, and his preoccupation with supposed "points of law" which never arose for consideration because the Government did not prevail on the facts. A point of law cannot fairly be presented as the basis for criticism of a trial judge unless the critic first establishes that the judge's decision was wrong on the facts. This is something that Professor Steffen has not merely not done; he has not attempted to do it.

Professor Steffen answers the argument that investment banking had undergone revolutions in competitive conditions by stating that the Government's reliance on evidence from an "earlier period" is explained not by its lack of awareness of these changes but by the comparative absence of evidence from defendants' files bearing date subsequent to the institution of the pre-complaint investigation. 3 But my point was not that the defendants should prevail because the Government relied mainly on evidence a decade old when the complaint was filed. Rather it was that they should prevail because what was in fact disclosed by that evidence refuted the charged of conspiracy. Mloreover, Professor Steffen fails to meet the point that, in a realistic, modern economy, decrees should not be issued on the basis of evidence of events which occurred practically a generation earlier.

The decision was that there had been no conspiracy-not that there had been none in 1953 (the decision date) or 1947 (the date of the complaint), but that there had been none at any time for which the Government chose to introduce evidence, whether 1945 or 1937 or 1933 or 1915 or 1905 -to take the dates which were most significant in the evidence as the Government presented it.

Lawyers must at time remind themselves that the law exists for the ends of justice, not of argument. Nevertheless, it is the function of a surrejoinder

$\doteqdot$ Member of the New York and Federal Bars. This is a reply to the immediately preceding article by Professor Steffen, The Intestment Bankers' Case: Obscrations in Rejoinder, 64 YaLE L.J. 863 (1955) (hereinafter cited as Steffen, Rejoinder).

1. Steffen Rejoinder, p. \&63.

2. The reference was to the "earlier generations of bankers" and the "revulutiun that has occurred in investment banking since that time." Whitney, The Imeistment Bankers' Case-Including a Reply to Professor Steffen, 64 Y YLE LJ. 319, 339 (1955) (hereinafter cited as Whitney).

3. Steffen Rejoinder, p. 869 . 
to follow arguments in rejoinder, however unrewarding that may seem to those who prefer reality. Among his "Observations in Rejoinder" Professor Steffen makes two "points of law," both of which turn on definition of the conspiracy in the complaint.

\section{"Integrated Over-all Conspiracy"}

When Professor Steffen says "Judge Medina committed manifest error, when he decided the case before him on the assumption that only a single conglomerate conspiracy had been charged," 4 he appears to be saying that a conspiracy had been proved but that it differed from the conspiracy which Judge Medina thought had been charged. Thus, Professor Steffen is saying that Judge Medina decided the case on a point of law, indeed on a pleading point. This is just not so. He decided the case on the facts and found that no conspiracy of any kind had been proved. Not merely "manifest error;" Professor Steffen goes on to say, but "reversible error." Can he beriously suggesting that a decision, right on the facts, is to be reversed because of an erroneous dictum as to what section of the Sherman Act the defendants would have violated if they had been found to have acted in conspiracy?

Professor Steffen particularizes his argument. He suggests that Judge Medina supposed that only a charge of monopoly, a section 2 charge, was involved, and not a charge of restraint of trade under section 1. This also is just not so. Judge Medina and Government counsel devoted most of the trial to the charge of conspiracy in restraint of trade, the section 1 charge. The major part of the time was not occupied with defendants' openings, as Professor Steffen suggests. ${ }^{6}$ All of the openings were completed in April 1951, and the time was then exclusively devoted to the presentation of the Government's evidence until it rested its case in March 1953. It is a strong indictment for a counsel, himself not present after June 1951, to suggest that the other counsel for the Government never succeeded, in two years of presentation of its case, in carrying to the Judge's consciousness the fact that a conspiracy in restraint of trade as well as a conspiracy to monopolize had been alleged.

When there is no conspiracy in fact, there can be no conspiracy in law. And if there be a conspiracy in fact, it is with that conspiracy, and no other, that the law must deal. If Professor Steffen means to say that law can punish as conspirators men who have not in fact conspired, then I respectfully disagree.

$$
\text { "Terms" and "Means" }
$$

Paragraphs 43, 44 and 45 of the complaint alleged many "terms" of which the conspiracy "consisted," together with many more "means" used to carry out these "terms." When Professor Steffen's original article implied that

4. Id. at 863 .

5. Id. at 864 .

6. Id. at 871 . 
paragraph 44 set out "means" only, and that paragraph 43 set out the "only" conspiracy in restraint of trade in the complaint, ${ }^{8}$ it compelled me to point out that:

"paragraph 44 ... did not confine itself to 'means' . . . the paragraph was a recital, not of 'means' only for carrying out the conspiracy, but of the very 'terms' of the conspiracy."

Now under the heading "Termus" and "Means" in his Rejoinder, Professor Steffen opens by agreeing that paragraph 44 does set out "terms" of the conspiracy. But he does so grudgingly, for he qualifies them as "subsidiary" only. He then converts my statement that paragraph 44 "did not confine itself to 'means" " and was "a recital not of 'means' only," into a statement "that paragraph 44 was little, if anything, but a recital "of the very "terms" of the conspiracy." "11 Having made that distortion, he charges me with "distortion,"12 and then warms to the task as follows:

"He [Whitney] then informs the reader-as he did the court-that everything following [the introductory clause of 44] is therefore really only a statement of 'terms.' In his view, it seems there were no 'means' alleged in the complaint."13

I am puzzled why Professor Steffen has tound it worthwhile to misquote me, unless it be that he feels a compelling need to cover his retreat. Retreat it is, for paragraph 44 is now admitted to have alleged "terms" of the "conspiracy," from which it follows that Judge Mledina was right in examining them in order to determine whether the conspiracy existed in fact. The Government's failure to prove the terms of the conspiracy alleged in paragraph 44 gains added significance from the fact that Professor Steffen conceded in his main article that "most of the [Government's] evidence in the case bore" on the allegations in paragraph 44 and that that was the "main thrust of the conspiracy" and "the core of the Government's case."1

Professor Steffen goes on to admit that "the plaintiff has the burden of establishing agreement upon the 'terms' of a conspiracy."15 But, caught at

7. Steffen, The Investment Bankers' Case: Some Obserations, 64 YaLE L.J. 169, 172-73 (1954) (hereinafter cited as Steffer:) :

"In Paragraph 44A, some of the 'means' are stated by which the defendants are alleged to have agreed 'not to compete among themsele's' in carrying out the conspiracy charged in Paragraph 43 ... In Paragraph 44B, the 'means' are stated by which the defendants are alleged to have agreed "to eliminate the competition of other inzestment. baukers' in carrying out the conspiracy."

See also $i d$. at 181 regarding $44 \mathrm{E}(1)$, and $i d$. at 182 .

8. Id. at $17 \dot{z}$ (emphasis in original).

9. Whitney, p. 325 (emphasis added).

10. Steffen Rejoinder, p. \$65. See also id. at $\$ 66-67$ ns. 22-24.

11. Id. at 865 .

12. Ibid.

13. Id. at 866 .

14. Steffen, pp. 173, 174, 177.

15. Steffen Rejoinder, p. 865 (emphasis added). 
this point, he doubles back and revokes the admission, saying once more that paragraph 43 alleges the "only" conspiracy in restraint of trade alleged in the complaint:

"defendants through their various activities [what he had just called their "various practices or 'means" "] were engaged in a common plan or scheme to eliminate price-competition between themselves, and to channelize distribution. That was the conspiracy in restraint of trade, and the only such conspiracy charged in the complaint."10

Professor Steffen has now come full circle, and returned to the proposition with which he started in his original article: that it was sufficient for the Government to prove only the allegations of paragraph 43 that the defendants conspired to restrain and monopolize "distribution, the purchase and sale of securities [a conspiracy unlawful] in two respects: (1) securities have been made to flow in controlled channels; (2) prices have been fixed and maintained."17 "That," he said, "is the conspiracy in restraint of trade-and the only such conspiracy-charged in the complaint."18

At the trial Professor Steffen was alone among Government counsel in taking this stand. He was present for only three months in a trial that lasted nearly three years. What became abundantly apparent, at least to other Government counsel, was that, unless the Government could establish conspiracy under the allegations of paragraph 44 ("triple concept" and all the rest of it), they could not establish conspiracy under 43 . This must indeed have been logically apparent to Professor Steffen when he drafted the complaint, for the extensive allegations of 44 and 45 were then presumably deemed essential to support 43.

There was in effect no independent evidence to support the allegations of 43 except the hundreds of syndicate agreements. And it was sufficiently obvious, both from the internal evidence gained by reading them and from the testimony of the Government's own principal witness, Mr. Harold L. Stuartsenior partner of perhaps the largest banking house in the business, and a non-defendant firm-that no one could infer a conspiracy on the part of the defendants from a mass of agreements alike only in that they contained the same essential features which distinguished the industry as a whole and without which a syndicate could not hold together nor the industry exist. ${ }^{10}$

It is right to say that the case, presented in Professor Steffen's waysolely on paragraph 43 , with the rest treated as superstructure only-would be nothing less than an attempt to destroy the independent business of investment banking as such, and to do so in an intellectually dishonest way, through the pretense of establishing a conspiracy on the part of the seventeen firms which the prosecution found to have been most successful in the business.

16. Id. at 867-68 (emphasis in original).

17. Steffen, p. 172 .

18. Ibid.

19. There is not space here to review the evidence, but see particularly the section of Judge Medina's opinion entitled "The Syndicate System," United States v. Morgan, 118 F. Supp. 621, 681-701 (S.D.N.Y. 1953). 


\title{
THE YALE LAW JOURNAL
}

\begin{tabular}{lll}
\hline Volume 64 & MAY, 1955 & Nuarber 6 \\
\hline
\end{tabular}

\author{
Jerosare A. CoHen \\ Editor-in-Chief
}

\begin{tabular}{|c|c|c|}
\hline $\begin{array}{l}\text { BaRRY R. BRYAN } \\
\text { Article and } \\
\text { Book Review Editor }\end{array}$ & $\begin{array}{l}\text { Whliasr H. Desipsey, JR. } \\
\text { Thomas F. Nezson } \\
\text { Gordon B. Sprick } \\
\text { Note and Comment Editor }\end{array}$ & $\begin{array}{l}\text { Gernld WaLPIN } \\
\text { Ifanaging Editor }\end{array}$ \\
\hline
\end{tabular}

IRVING J. AITER

Peter W. ANson

ROBERT IV. BEREND

Daniel M. Berger

MURRY D. BrochIN

Thonas N. Carrut

Donald J. COHN

John W. Colleran

Aran P. Colodny

Edrund V. Conway

Geratd MI. Doppeit

S. GoRDON ELKINS

JOEL M. FEINBERG

JOSEPH M. FIELD

BARRY H. GaRFINKEL

Charles S. Haight, JR.

\author{
ROBERT J. HARRIS \\ Grorge C. Hastings \\ Ira MifGaEl Heyaran \\ Alexander P. Hofrarans \\ Charles D. Isaac \\ LAwRENCE R. KLEIN \\ NOEL ARNOLd LEVIN \\ Charles S. Mecheas, Jr. \\ RALPH C. MENAPACE, JR. \\ EDWARD A. MiLLER \\ JON O. NEWMYAN \\ LAWRENCE NEWMAAN \\ Martin Oppenhetarer \\ Otts P. Pearsail \\ Richard H. Pershan
}

Hers, JR. DAVtd B. IsBeLL
Stephen J. Pollak

Maruin N. Rrasar

Bernard S. Rondiss

Nonoert A. Schler

Raizrono Al. SnaIseseg

Walter E. Shuttleworth

JeINANE RITCHIE SILIER

Monroe Sulerasa::

Rorert J. Sisk

ArLex Specter

MIELTIN STEI:

Jorn SUbak

Charles H. Vejroda

ROGER A. WELCB

Howard P. WhLeNS

Geosge C. ZACHARY

Marie MicMiamon

Business Secretary

\section{CONTRIBUTORS TO THIS ISSUE}

Feidx ERankfurter. A.B. 1902, College of the City of New York; LL.B. 1905, Harvard University. Associate Justice of the Supreme Court of the United States.

Eugene V. Rostow. B.A. 1933, LL.B. 1937, M1.A. 1944, Yale University. Professor of Law, Yale Law School.

Kard Loewenstern. LL.B. 1914, LL.D. 1919, Mrunich University. William Nelson Cromwell Professor of Jurisprudence and Political Science, Amherst College. Alember of the Mrassachusetts Bar. Consultant, United States Miilitary Government for Germany, 1941-45, 1947-48, 1950. Author: Hitrer's Gerarany (1939); Political Reco:tstruction: (1946); DIE Monarceire iar nodernen StaAt (1952); and various other books.

H. T. Kopirv. A.B. 1947, Oberlin College; Ph.D. 1952, Cornell University. Assistant Professor of Economics, University of Oregon. Fellow, Ford Foundation Fund for the Advancement of Education, Oxford University 1954-55.

Roscoe Stefrex. For biographical data see the December issue of the Yale Law JoURNAL page 221.

WMr. DWIGHT Whitney. For biographical data see the January issue of the YalE Law Journal page 390. 